\title{
REGISTRATION OF COMPANY CHARGES REVISITED: NEW AND FAMILIAR PROBLEMS
}

\author{
Alisdair D J MacPherson*
}
A. INTRODUCTION
B. REGISTRATION OF CHARGES: BACKGROUND
C. WHAT IS A “CHARGE”?

(1) General

(2) Assignation in Security

(3) Floating Charge

(4) A Functional Definition?

D. WHEN IS A CHARGE CREATED?
(1) Standard Security
(2) Assignation in Security
(3) Floating Charge

E. EFFECTIVENESS OF UNREGISTERED CHARGES
(1) General
(2) Against the Company
(3) Against an Acquirer of Property
(4) Against Unsecured Creditors
(5) For Appointment of a Receiver or Administrator
(6) Against Claim Debtors
(7) Against Other Parties

F. REGISTRATION OF CHARGES OVER ACQUIRED PROPERTY
(1) Standard Security
(2) Assignation in Security
(3) Floating Charge

G. CONCLUSION 


\section{A. INTRODUCTION}

The law of registration of company charges is of considerable importance throughout the jurisdictions of the UK. Corporate finance transactions often depend upon the creditor obtaining valid security over the debtor's property. For such a security right to be fully effective, the registration of charges rules must be complied with. Yet despite its significance, there is a general absence of detailed analysis of the current law of registration of company charges in Scotland. ${ }^{1}$ The previous law received a degree of scholarly attention ${ }^{2}$ and the present regime also requires to be appropriately scrutinised.

This article therefore focuses on: what is meant by a "charge", when charges are deemed to be created, the effect of an unregistered charge, and the applicability of the provisions on registration of charges where a company acquires property already subject to a charge. It will be shown that some of the criticisms levelled against the predecessor registration of charges regimes remain valid ${ }^{3}$ and that, despite its overall positive impact, the current law contains significant points of uncertainty and difficulty. The article deals with conceptual and practical matters. It addresses issues that have not been discussed in the relevant literature. Legal practitioners involved in secured finance transactions and associated litigation in Scotland require to have in-depth knowledge of much of the registration of charges law that is considered in this article. In addition, the discussion of the potential uniformity of English law and Scots law on certain points, despite the existence of different systems of property law and security rights, may be a source of interest for those based outside Scotland, within both practice and academia.

\footnotetext{
* Lecturer in Commercial Law, School of Law, University of Aberdeen. I am grateful to Professor George Gretton, Dr Andrew Steven and the anonymous reviewer for their comments on earlier drafts of this article.

${ }^{1}$ There has been some commentary, see e.g. H Patrick, "Charges Changing" (2013) 58(2) JLSS 20 which is a short article outlining changes brought about by the new law; G Morse (ed), Palmer's Company Law 25 $5^{\text {th }}$ edn (Looseleaf) (1992-) paras 13.401ff which provides brief commentary on certain aspects of the regime; and see also J Hardman, A Practical Guide to Granting Corporate Security in Scotland (2018) paras 10-03ff.

${ }^{2}$ See e.g. W W McBryde and D M Allan, "The Registration of Charges" 1982 SLT (News) 177; G L Gretton, "Registration of Company Charges" (2002) 6 EdinLR 146. See also Scottish Law Commission, Report on Registration of Rights in Security by Companies (Scot Law Com No 197) (2004).

${ }^{3}$ On this point, see also K G C Reid and G L Gretton, Conveyancing 2013 (2014) 172-178.
} 


\section{B. REGISTRATION OF CHARGES: BACKGROUND}

A regime for the registration of "charges" granted by a company was introduced to Scots law by the Companies (Floating Charges) (Scotland) Act 1961 ("1961 Act"). ${ }^{4}$ English law had required company charges to be registered with the Registrar of Companies since 1901 in order to overcome problems arising from the lack of publicity in relation to charges. ${ }^{5}$ But the traditional Scots law adherence to the publicity principle in the creation of security rights meant that, until 1961, there was no perceived need for (additional) registration in that system. ${ }^{6}$ The position changed, however, with the arrival of the floating charge.

There was a recognition that the Scots law floating charge ought to be accompanied by a mechanism for registration against the person of the chargor. This would publicise the encumbrance of all or any part of the chargor's property. Given that the floating charge was being transplanted from English law, the English system of registering floating charges was also copied. However, like English law, the adopted scheme for the registration of charges extended beyond floating charges to other forms of security. ${ }^{7}$ The justification provided in the 1961 Act, section 6, was that floating charges and other charges "ought to be published for the information of persons considering taking security... by way of floating charge". ${ }^{8}$ In other words, the registration of charges system was (at least in part) to be an information nexus for prospective floating charge holders, as regards certain security rights already created by the company. Due to the desire to encourage investment in Scottish companies by offering floating

\footnotetext{
${ }^{4} 1961$ Act s 6 and Second Schedule, which introduced a new Part IIIA (ss 106A-106K) into the Companies Act 1948.

${ }^{5}$ Companies Act 1900 ss 14-18, which came into force on 1 January 1901. This legislation followed on from the recommendations of the Davey Report (Cmnd 7779) (1895). There had been a requirement for registered limited companies to keep an internal register of mortgages and charges since the Companies Act 1862 s 45, but this could only be inspected by company members and existing creditors. Non-registration did not render charges invalid but fines could be imposed for failure to comply. In general terms, the publicity principle has often been disregarded in the English tradition.

${ }^{6}$ Indeed, the floating charge was rejected at common law (in part) due to its non-compliance with the publicity steps used to create voluntary security over property: Carse v Coppen 1951 SC 233 at 239 per Lord President Cooper. See also W M Gloag and J M Irvine, Law of Rights in Security: Heritable and Moveable Including Cautionary Obligations (1897) 7 where it is stated that the creation of a right in security in Scots law (generally) requires an "overt act" to make third parties "aware of the preference so acquired".

${ }^{7}$ Including charges on land and security over various types of incorporeal moveable property, such as book debts of the company and intellectual property: Companies Act 1948 s 106A(2), as introduced by 1961 Act, Second Schedule.

${ }^{8}$ This is more of an explanation than is provided in the report that preceded the 1961 Act: Law Reform Committee for Scotland, Eighth Report of the Law Reform Committee for Scotland (Cmnd 1017) (1960) para 50.
} 
charges, it is understandable that an attempt was made to minimise the resource implications of gathering information regarding prior security rights. The information provided would also be of benefit to others dealing with the company. Yet, on the other hand, additional costs and inconvenience were imposed upon the company and secured creditors by the requirement for double registration of some security rights. ${ }^{9}$

Over the following decades, the various iterations of the registration of company charges regime were the subject of criticism by commentators. ${ }^{10}$ Professor Gretton described the applicable statutory provisions as "a rich source of difficulty" and recommended the abolition of the registration of charges system, due to it being unnecessary (from a publicity perspective) for security rights other than the floating charge. ${ }^{11}$ The Scottish Law Commission also recommended such an approach. ${ }^{12}$ The registration of charges has persisted but the most significant changes to that system came into force on 6 April 2013 when chapter A1 was inserted into Part 25 of the Companies Act 2006. ${ }^{13}$ There is now a UK-wide scheme of registration of charges in place of the previously separate (but substantively similar) schemes for Scotland and the rest of the UK. ${ }^{14}$ It is possible to view this as a natural convergence led by commercial considerations. In introducing floating charges and registration of charges in 1961, Scots law was replicating aspects of English law to promote the business of Scottish companies and a combined system of registration seems like a logical further development which increases cross-border uniformity of laws and facilitates ease of lending across the UK. ${ }^{15}$

\footnotetext{
${ }^{9}$ For security rights over heritable property and over some incorporeal moveable property. For most incorporeal moveable property, however, registration in the charges register follows intimation to a claim debtor, which is double "publicity" of a different kind (intimation can be considered an external act rather than true publicity).

${ }^{10}$ See e.g. D A Bennett, "A Judicial Wet Blanket upon the Register of Charges" 1967 SLT (News) 153; McBryde and Allan (n 2); Gretton (n 2).

${ }^{11}$ Gretton (n 2) at 147 and 175.

12 The Scottish Law Commission, Report on Registration of Rights in Security by Companies (n 2) para 3.25, recommended abolition and the introduction of a new Register of Floating Charges. Such a register was to have been introduced by Part 2 of the Bankruptcy and Diligence etc (Scotland) Act 2007. However, it now appears as if Part 2 will never be brought into force. In any event, this would not abolish the registration of charges scheme.

${ }^{13}$ Added by the Companies Act 2006 (Amendment of Part 25) Regulations 2013/600, regs 23 , and Sch 1, para 1, in place of chapters 1 and 2 of Part 25. Earlier attempts at reform (including more radical proposals) had notably failed: for brief discussion see e.g. Gretton (n 2) at 147 and 175.

${ }^{14}$ A combined system for Great Britain was meant to have been introduced years earlier by the Companies Act 1989 ss 92-100, but this was never brought into force.

${ }^{15}$ For analysis of economic advantages arising from conformity between English law and Scots law in the area of security rights see J Hardman, "Some Legal Determinants of External Finance in Scotland: A Response to Lord Hodge" (2017) 21 EdinLR 30.
} 
Given the dissimilarities between the Scots and English laws of security rights, such as terminological differences, the types of security available and the absence of equity in Scots law, the creation of a system which caters for both sets of laws is a notable achievement. ${ }^{16}$ It may also mean that the courts will give particular regard to consistency of interpretation across the jurisdictions. ${ }^{17}$ However, since registration of charges must operate against the background of the wider legal system, there would be no end of technical difficulties if the Scottish law of security rights was overridden or disregarded. There are still elements of registration of charges that are distinct to each jurisdiction and this article will analyse aspects of the current regime from the perspective of Scots law, but with reference to the English position where that is useful for interpretive purposes.

\section{WHAT IS A “CHARGE"?}

\section{(1) General}

Section 859A of the Companies Act 2006 provides details regarding registering charges. The section applies "where a company creates a charge", ${ }^{18}$ and only these "charges" fall within the registration of charges regime. A charge by its nature is a form of security over property and thus cautionary obligations are outside the registration of charges system. The requirement that the company "creates" the charge also excludes security rights that the company does not voluntarily grant. This exclusion extends to securities arising by operation of law, such as liens

\footnotetext{
${ }^{16}$ The regime in fact seeks to integrate the laws of England and Wales, Northern Ireland and Scotland.

${ }^{17}$ On one view, where the same provisions are applicable across the UK, decisions of the UK Supreme Court (and formerly the House of Lords) are binding in all of the UK jurisdictions: see e.g. Virtue $v$ Commissioners of Police of Alloa (1874) 1 R 285, especially per Lord President Inglis at 296-297; Dalgleish v Glasgow Corporation 1976 SC 32 per Lord Justice Clerk Wheatley at 51-52. Cf McDonald v Secretary of State for Scotland 1994 SC 234 per Lord Justice Clerk Ross at 240. For discussion, see N Walker, Final Appellate Jurisdiction in the Scottish Legal System (2010) Appendix III, 58ff.

${ }^{18} \mathrm{~S} 859 \mathrm{~A}(1)$.
} 
and the landlord's hypothec, and judicial securities (diligences). ${ }^{19}$ In addition, there are some express exclusions within s 859A. ${ }^{20}$

Nevertheless, the general rule in the current provision is that all charges created by a company over its property are registrable. Formerly, only floating charges and charges over specific types of property (e.g. land, ships and aircraft, and certain types of incorporeal moveable property, such as intellectual property and book debts) fell within the regime. ${ }^{21} \mathrm{~A}$ system which provides that voluntarily created charges are registrable unless excluded should provide greater certainty as to whether something is a registrable charge or not. ${ }^{22}$ However, it still leaves the question of what does the term "charge" cover?

It is stated in s $859 \mathrm{~A}(7)$ that a charge includes "a standard security, assignation in security, and any other right in security constituted under the law of Scotland, including any heritable security, but not including a pledge". ${ }^{23}$ In Scots law, the principal types of real rights in security are the pledge, for corporeal moveable property, and the standard security, for heritable property (mainly land). The former is expressly excluded, while the latter is expressly included. Since 1970, the standard security has been the only form of voluntary heritable security available in Scots law. ${ }^{24}$

\section{(2) Assignation in Security}

Assignation in security is also mentioned in the definition in s 859A(7). The consensus view is that this is a functional form of security in Scots law whereby incorporeal property is transferred to the assignee for security purposes. ${ }^{25}$ It is not a true (subordinate real) right in

\footnotetext{
${ }^{19}$ Thus, registration of charges is only applicable to one of the three types of security within the traditional taxonomy of such rights in Scots law. For the taxonomy see e.g. Bell, Commentaries, II, 10. Cf G L Gretton and A J M Steven, Property, Trusts and Succession, $3^{\text {rd }}$ edn (2017) ch 21 where a different taxonomy is used to take account of charging orders. ${ }^{20} \mathrm{~S}$ 859A(6). One of these excluded categories comprises charges excluded by or under any other Act (s 859A(6)(c)), such as security financial collateral arrangements under the Financial Collateral Arrangements (No 2) Regulations 2003 SI 2003/3226, regs 3-4.

${ }^{21}$ See Companies Act 2006 s 878(7), as introduced.

${ }^{22}$ Hardman, Corporate Security para 10-03 also expresses support for this change to the law.

${ }^{23} \mathrm{~S}$ 859A(7).

${ }^{24}$ Conveyancing and Feudal Reform (Scotland) Act 1970, s 9. It is therefore uncertain what else "any heritable security" in the definition could refer to. Some non-registered heritable property can be subject to an assignation in security, but this security is already expressly covered in the definition.

${ }^{25}$ See e.g. Scottish Law Commission, Report on Moveable Transactions (Scot Law Com no 249) (2017) paras 13.44-13.45; Scottish Law Commission, Discussion Paper on Moveable Transactions (DP 151) (2011) para 7.6; G L Gretton, "The Concept of Security" in D J Cusine (ed), A Scots Conveyancing Miscellany: Essays in Honour of Professor J M Halliday
} 
security. ${ }^{26}$ The transfer is completed by intimation to the claim debtor (or an equivalent step) ${ }^{27}$ and requires retransfer (retrocession) to the cedent (assignor) when the secured debt is satisfied. There are two general forms of assignation in security: assignation expressly in security and assignation ex facie absolute qualified by back letter or agreement. No distinction is drawn in the definition between the different types of assignation in security. Both of them presumably constitute "charges". It is, however, sometimes difficult to discern whether what appears to be a non-security absolute assignation is, in fact, an assignation in security and thus ought to be registered. This is especially true if the cedent has a conditional right to have the property transferred back to them or can obtain such a right. Where there is a statement that the assignation is for security purposes then this will indicate that a charge has been created. ${ }^{28}$ But even if there is no such statement, if property is assigned to minimise or neutralise the risk of non-performance of a separate obligation owed to the assignee, and the assignee is obliged to re-transfer the property upon satisfaction of that separate obligation, ${ }^{29}$ then the assignation should be deemed a security and thus a registrable charge. ${ }^{30}$

\section{(3) Floating Charge}

Whether a floating charge is included under the legislation simply due to its nature and nomenclature or because it is a "right in security constituted under the law of Scotland", it is

(1987) 130; R G Anderson, Assignation (2008) para 7-36. See also the discussion of relevant authorities at A D J MacPherson, The Attachment of the Floating Charge in Scots Law, (PhD Thesis, University of Edinburgh) (2017) 240ff. For a recent case which may be viewed as a departure from the consensus position, see Edinburgh Schools Partnership Ltd v Galliford Try Construction (UK) Ltd [2017] CSOH 133; 2017 GWD 35-540.

${ }^{26}$ If registration of charges was limited to such rights then it would exclude incorporeal moveable property, as there is no real security available for this property. However, the statutory pledge recommended by the Scottish Law Commission would constitute a subordinate real right over particular types of incorporeal moveable property, i.e. financial instruments and intellectual property: Scottish Law Commission, Report on Moveable Transactions (n 25) ch 16.

${ }^{27}$ E.g. registration for certain incorporeal moveable property, such as patents.

${ }^{28}$ Less credence should be given to where it is stated that the transaction is not a security, as this may simply be an attempt to unfairly avoid the regime for registering charges. Such a statement should be taken into account but the substance of the transaction is decisive.

${ }^{29} \mathrm{Or}$, if there are surplus proceeds arising from the assigned property, the assignee is obliged to provide these to the cedent. If the assigned property is instead insufficient to satisfy the separate obligation, then the remaining debt is likely to be recoverable from the cedent if the transaction is a secured one.

${ }^{30}$ This would also apply if the separate obligation was owed by another party. In addition, it would seem to apply where the cedent merely has the option to have the property retrocessed upon fulfilment of the separate obligation. 
undoubtedly a registrable charge. ${ }^{31}$ A floating charge is a voluntary security created over potentially all of a company's property from time to time, whether moveable or heritable. ${ }^{32}$ However, it does not provide a real right in property when it is created. It is only upon its attachment that it is considered to give its holder a real right in the charged property. ${ }^{33}$

\section{(4) A Functional Definition?}

The inclusion of assignation in security and the floating charge within the meaning of "charge", extends the term beyond rights in security in the narrow sense, i.e. immediate subordinate real rights in security. Instead, it involves an approach to security rights that incorporates the transfer of property as security (assignation in security) and security which does not confer an immediate real right (floating charge). Within the definition of "charge", the express mention of standard security and assignation in security may be considered examples of the types of security encompassed by that definition i.e. subordinate real securities and the transfer of property as a security right. Alternatively, an interpretation of "charge" which more narrowly limits the term's meaning can be adopted. This is the case if the definition is generally limited to real rights in security, if the inclusion of assignation in security within the definition of "charge" therefore required express mention, and a floating charge by its nature is exceptional and automatically included. Yet this view is somewhat undermined if the previous version of the charges regime is used to assist with interpretation. That system did not expressly refer to assignation in security. Instead, the statutory reference to "security over incorporeal moveable property" ${ }^{\prime 34}$ was considered to automatically apply to assignation in security, despite its status as a functional security. Thus, "security" was interpreted broadly.

It is possible to interpret the phrase "any other right in security constituted under the law of Scotland", within the current definition, as corresponding to rights in security in a narrow or wide sense of the term. ${ }^{35}$ If it is the latter, then some additional "functional" forms

\footnotetext{
${ }^{31}$ This is consistent with the policy behind the introduction of the floating charge. And see A J M Steven, "Reform of Security over Moveables: Still a Longstanding Reform Agenda in Scots Law" in D Bain, R R M Paisley, A R C Simpson and N J M Tait (eds), Northern Lights: Essays in Private Law in Memory of Professor David Carey Miller (2018) 217 at 220. ${ }^{32}$ Companies Act 1985 s 462(1).

${ }^{33}$ National Commercial Bank of Scotland v Liquidators of Telford Grier Mackay \& Co 1969 SC 181.

${ }^{34}$ In the now-repealed s 878(7)(b) of the Companies Act 2006, and previously in the Companies Act 1948 s 106A(2)(c), as amended, and in the Companies Act 1985 s 410(4)(c).

${ }^{35}$ See Gretton (n 25) for different meanings of rights in security. And see now J MacLeod, "Thirty Years After: The Concept of Security Revisited" in A J M Steven, R G Anderson and
} 
of security may constitute registrable charges ${ }^{36}$ Prime candidates would be sale and leaseback arrangements being used for security purposes ${ }^{37}$ (these would not have been registrable under the old regime as corporeal moveable property was not a type of property affected by that regime) and the creation of a trust as security in relation to company property. ${ }^{38}$ Both of these involve the transfer of property as a means of giving security to a creditor that is providing finance. ${ }^{39}$ Recognising them as "charges" would not only be consistent with a broad view of security rights in Scots law, it would also align the position more closely with the transactions that are registrable under English law (albeit that the two systems use different means of establishing what constitutes a security). ${ }^{40}$ The latter point might be considered appropriate as a result of the move to a combined regime and greater uniformity. They are also both forms of

\section{J MacLeod (eds), Nothing so Practical as a Good Theory: Festschrift for George L Gretton} (2017) 177.

${ }^{36}$ An argument could even be made that the definition of "charge" for Scots law in s 859A is wider than English law, as the definition of the latter only refers to the fact that it includes mortgages, although it obviously also includes "charges" in the strict sense in English law. ${ }^{37}$ Most notably where the "seller" has to fulfil an obligation to the "buyer" and, upon such fulfilment, has the right to re-acquire ownership of the property. An example would be a "sale and hire purchase back" transaction where the "seller" has received payment for the sale and then takes the property on hire, pays the "buyer" in instalments and can regain ownership upon paying a final amount to satisfy the outstanding obligation. A further possibility for a transaction constituting a "charge" would be a "sale and sale back transaction", where the "seller" is obliged to repurchase the property on agreed terms. (As regards the latter, see Curtain Dream plc v Churchill Merchanting Ltd [1990] BCC 341 for an English case in which a sale and sale back transaction was deemed to create a registrable charge.) Given that each of these involves the transfer of property as security, this general type of transaction can be considered a broad equivalent of assignation in security but for corporeal moveable property.

${ }^{38}$ Regarding the possible registration of trusts used for security purposes, see also A D J MacPherson, "Floating Charges and Trust Property in Scots Law: A Tale of Two Patrimonies?" (2018) 22 EdinLR 1 at 20.

${ }^{39}$ With respect to a trust, the transfer may simply be a transfer from the company's general patrimony into its trust patrimony.

${ }^{40}$ The Scots law of security rights is formalistic insofar as it requires the use of real rights (by e.g. creation of real security rights or transfer of ownership) for a party to obtain a "security" over property. English law is also formalistic but in a different way, as something must fall within one of four categories to be a voluntary security (pledge, mortgage, charge and contractual lien - see e.g. Re Cosslett (Contractors) Ltd [1998] Ch 495 per Millett LJ at 508). In English law, the creation of a trust as a security device would be an equitable mortgage or charge (in the strict sense) and thus a registrable charge, and the use of sale and leaseback for security purposes could be a mortgage or charge (in the strict sense) and therefore registrable too in some circumstances, see e.g. E McKendrick (ed), Goode on Commercial Law, $5^{\text {th }}$ edn (2016) paras 22.16, 22.24-22.25, 22.29-22.31 and 24.31, for discussion of the relevant law. And see Re George Inglefield [1933] Ch 1 per Romer LJ at 27-28, for details of indicia of mortgages and charges in comparison to a true sale transaction. 
"security" for which publicity is often lacking at present. ${ }^{41}$ Requiring their registration as charges would give a more complete picture regarding security rights affecting the company's property and would thus offer further publicity to those considering dealing with the company. This would bolster the role of the register as an information point and thereby go some way to meeting the criticism that the register is not sufficiently comprehensive regarding security rights created by a company. ${ }^{42}$ The status of the register as an information source for company charges will be extended even further if statutory pledges are introduced, as the Scottish Law Commission considers that these will also have to be registered. ${ }^{43}$

Yet even if "charge" is interpreted widely, its extent would still be limited. Certain functional securities would remain excluded from the regime, such as hire purchase and reservation of title. ${ }^{44}$ If a seller is retaining ownership as a security, this does not involve creating a security in favour of another party. And there is no possibility of the seller's "security" being registered against the buyer in the charges register, as the latter does not yet own the property. The position would be different under a true functionalist system such as the Uniform Commercial Code Art 9 (USA) or a Personal Property Security Act (as in e.g. Australia, New Zealand, and the Canadian provinces other than Quebec) in which recharacterisation of transactions takes place. ${ }^{45}$ If, however, the buyer in a retention of title

\footnotetext{
${ }^{41}$ With respect to sale and leaseback (and its variants), delivery is necessary to transfer ownership where the transaction is "intended to operate by way of mortgage, pledge, charge, or other security", due to the operation of Sale of Goods Act 1979 s 62(4). But the delivery to the "purchaser" and re-delivery to the "seller", for them to use the property, could even happen in private and a third party may not realise that the "seller" at some point transferred possession (and ownership). See the examples given at J Hamilton et al, Business Finance and Security over Moveable Property (Scottish Executive Central Research Unit) (2002), para 3.130.

${ }^{42}$ The register would, however, still be deficient in other respects as regards comprehensiveness of security rights granted, see Gretton (n 2) for various criticisms.

${ }^{43}$ Scottish Law Commission, Report on Moveable Transactions (n 25) para 36.9.

${ }^{44}$ Patrick (n 1) at 20, states that functional securities such as hire purchase were not intended to be registrable under the new regime.

${ }^{45}$ For example, with retention of title the "buyer" would acquire ownership and the "seller" would merely have a security interest: see e.g. Scottish Law Commission, Report on Moveable Transactions (n 25) para 18.8. See also L Gullifer, “'Sales' on Retention of Title Terms: Is the English Law Analysis Broken?” (2017) 133 LQR 244 at 264-268 who argues in favour of a functional approach to retention of title transactions in English law whereby the property would transfer to the buyer and the seller would have a floating charge over the property.
} 
situation in Scots law was required to hold proceeds from the sale of property in trust as security for the seller, this could amount to a charge. ${ }^{46}$

It is true that a wide interpretation of "charge" has disadvantages. There is greater uncertainty regarding whether a particular transaction constitutes a security. ${ }^{47}$ It would also mean parties having to register additional types of security with Companies House, but in policy terms that might be viewed as a price worth paying. Unfortunately, it is not possible to say with any conviction what the current law is but the points outlined above indicate that there is at least a reasonable argument in favour of a wide interpretation as well as merit in such an approach. In cases of doubt, the safest course of action is, of course, to attempt to register the potential charge with Companies House. It is understood that Companies House will not refuse to register a "security" simply because it is a functional security but will instead examine the substance of the transaction and the wording of an instrument to determine if a charge has been created.

Due to the uncertainty regarding what is meant by "charge", the following discussion will revolve around three types of security that are undeniably subject to the registration of charges regime: the standard security; assignation in security; and the floating charge. ${ }^{48}$

\section{WHEN IS A CHARGE CREATED?}

The date of the creation of a charge is the starting point for the time period within which a statement of particulars and a copy of the charge instrument require to be delivered for registration in the charges register. ${ }^{49}$ The relevant period for delivery is twenty-one days beginning with the day after the charge's creation date. ${ }^{50}$ Thus, although it is often said that registration must take place within that time period, it is actually delivery of the necessary documentation to the Registrar of Companies that is crucial. Consequently, references in the

\footnotetext{
${ }^{46}$ For the English position on this, see e.g. E McKendrick (ed), Goode on Commercial Law, $5^{\text {th }}$ edn (2016) paras 22.34-22.35.

${ }^{47}$ Albeit that there can already be some doubt about whether, for example, a transaction is an assignation in security or an absolute assignation (see above).

${ }^{48}$ There are other "charges" that are certainly subject to the regime, such as aircraft and ship mortgages, but these are limited to very specific types of property.

${ }^{49} \mathrm{~S} 859 \mathrm{~A}(2)-(3)$.

${ }^{50} \mathrm{~S} 859 \mathrm{~A}(4)$. If the delivery does not take place within the required period, it is possible to apply to the court for an extension of the delivery period under s 859F. See Gretton (n 2) at 168-171 for discussion of when this will be granted (with reference to the regime under the Companies Act 1985).
} 
literature to a chargee requiring to register should be considered a shorthand reference to the delivery requirement.

The current law regarding when a charge is created represents a significant change from the previous position, at least for certain charges. Formerly, the creation date was "the date on which the right of the person entitled to the benefit of the charge was constituted as a real right". ${ }^{51}$ The exception was the floating charge, which was created on "the date on which the instrument creating the floating charge was executed by the company creating the charge". 52 Now, there is a table in s $859 \mathrm{E}(1)$ of the Companies Act 2006, which is used to ascertain the creation date of the various types of charge.

\section{(1) Standard Security}

The position for the creation date of a standard security is outlined clearly; the "charge" is created upon its date of recording in the Sasine Register or registration in the Land Register of Scotland. ${ }^{53}$ This is the same as the previous position. It means that there is still a period of time between the security becoming a real right and this information being available on the charges register, due to the period allowed for the delivery of the documentation relating to the charge. This is a notable drawback of the charges register and for standard securities could be resolved by use of the information-sharing powers available under the Companies Act $2006 .{ }^{54}$ This would enable details of registration in the Land Register to be shared automatically with the charges register. It would bolster the charges register as an accurate reference point, there would be no need for a party dealing with the company to also consult the Land Register to establish the existence of the charge, and double registration would no longer be necessary. Given the technology available, it is disappointing that these information-sharing powers have not been utilised. ${ }^{55}$

\footnotetext{
${ }^{51}$ Companies Act 2006 s 879(5)(b) (repealed).

${ }^{52}$ Companies Act 2006 s 879(5)(a) (repealed).

${ }^{53}$ It is the only type of security that has its own entry in the table within s $859 \mathrm{E}(1)$. Note, however, that since 1 April 2016 all new standard securities must be registered in the Land Register (not recorded in the Sasine Register): see K G C Reid and G L Gretton, Land Registration (2017) para 7.12.

${ }^{54} \mathrm{~S} 893$.

${ }^{55}$ See generally Scottish Law Commission, Report on Moveable Transactions (n 25) ch 36.
} 


\section{(2) Assignation in Security}

Assignations, in practice, require to be created using a document. ${ }^{56}$ As a result, they fall within the second category in the table in s $859 \mathrm{E}(1)$, as a "charge other than a standard security, where created or evidenced by an instrument". Within that category, the first entry is the relevant one, as the relevant instrument "is a deed that has been executed and has immediate effect on execution and delivery". ${ }^{57} \mathrm{~A}$ deed is defined in relation to Scots law as "an instrument... which requires delivery under that law in order to take effect". ${ }^{58}$ This applies to assignation. ${ }^{59}$ For an assignation in security, the date of creation will therefore usually be the date that the assignation document is delivered to the assignee following execution. ${ }^{60}$ Under the previous law, by contrast, an assignation in security was created upon its intimation to the claim debtor.

One implication of the new creation date is that an assignation in security will be "created" before it has effect as a security in Scots law. This differs from the former position and the applicable creation date for standard securities. A claim will only be transferred to an assignee by assignation once intimation is made, ${ }^{61}$ and this can only take place after delivery of the assignation. The disparity between creation under the registration of charges scheme and effectiveness of the security in the wider law is recognised in s $859 \mathrm{E}(3)$, which states that the section applies for the purposes of the relevant Chapter "even if further forms, notices, registrations or other actions or proceedings are necessary to make the charge valid or effectual for any other purposes".

An assignation in security can also be registered in the charges register before it becomes effective. In fact, it can be so registered even if it never becomes effective, due to lack of intimation (or equivalent). These points may mean that the register could mislead third parties regarding the existence of an operative assignation in security. However, the likelihood is that, if an assignation in security is disclosed by the register, it is already effective or is shortly to become so, and the interested party will be put on notice regarding the impending security. ${ }^{62}$ The charges register serves a useful function for assignation in security as

\footnotetext{
${ }^{56}$ See Anderson, Assignation (n 25) paras 6-01 and 7-17.

${ }^{57} \mathrm{~S} 859 \mathrm{E}(1)$.

${ }^{58} \mathrm{~S} 859 \mathrm{E}(5)(\mathrm{b})$.

${ }^{59}$ See Anderson, Assignation (n 25) paras 6-30-6-31 and 10-09-10-11.

60 This is also the view of Patrick (n 1) at 20.

${ }^{61}$ See Anderson, Assignation (n 25) ch 6 . The Scottish Law Commission has recommended introducing registration in a Register of Assignations as an alternative to intimation: Scottish Law Commission, Report on Moveable Transactions (n 25).

62 Thus, interested parties can be considered to have a degree of foresight regarding the effectiveness of an assignation in security. However, under the old system, a party would
} 
registration provides a stronger form of publicity than intimation. ${ }^{63}$ The moving forward of the creation date is therefore welcome from a publicity point of view, but there is still a distinct possibility of a period between intimation of an assignation and the charges register disclosing the assignation's existence, albeit this is likely to be a shorter period than before. ${ }^{64}$ Early registration could also have advantages for a prospective assignee. It might, for example, allow them to invoke successfully the "offside goals" rule against a subsequent assignee who intimates first. ${ }^{65}$ In many cases, however, this will not be necessary as intimation will take place prior to registration in the charges register.

\section{(3) Floating Charge}

The date of creation of a floating charge by a Scottish company was formerly the date when the charge instrument was executed by the chargor company. ${ }^{66}$ Now, it is generally considered to be the date when the floating charge instrument is delivered to the chargeholder, following execution. ${ }^{67}$ This is the same creation rule as for assignation in security.

Yet the applicability of this rule to floating charges depends upon a floating charge instrument being a "deed" under the legislation. To be a deed, an instrument must require delivery under Scots law to take effect. ${ }^{68}$ Determining whether this is true for the floating charge is not free from doubt. Floating charges are not recognised at common law and the

know that if an assignation in security was disclosed by the register, intimation had taken place and the charge was effective (unless it had been discharged).

${ }^{63}$ If intimation can be considered a true form of publicity at all. See Anderson, Assignation ( $\mathrm{n}$ 25) paras 6-04-6-06.

${ }^{64}$ I.e. if intimation takes place shortly after delivery, a proportion of the time period allowed for delivery to the Registrar of Companies may still be available.

${ }^{65}$ If the subsequent assignee has notice of the earlier assignation. It is not clear how widely the doctrine of constructive notice applies as regards the Companies Register. For details of the offside goals rule, see e.g. K G C Reid, The Law of Property in Scotland (1996) paras 695-700. Given that an assignation in security involves the transfer of property, it is not possible to have multiple such securities in relation to the same property. The cedent can though assign its retrocession (reversionary) right, and can even do so in security: see G L Gretton and K G C Reid, Conveyancing, $4^{\text {th }}$ edn (2011) para 23-06. Since the charges register discloses assignations in security after delivery, not intimation, multiple assignations in security could, theoretically, be disclosed on the register, albeit that only one could ultimately become an effective security.

${ }^{66}$ Companies Act 2006 s 879(5)(a). And before that, see Companies Act 1985 s 410(5)(a); Companies Act 1948 s 106A(10)(a). See also AIB Finance Ltd v Bank of Scotland 1993 SC 588.

${ }^{67}$ See e.g. Scottish Law Commission, Report on Moveable Transactions (n 25) para 36.7; Morse (ed), Palmer's Company Law (n 1) para 13.207; Patrick (n 1) at 20 and 22.

${ }^{68} \mathrm{~S} 859 \mathrm{E}(5)(\mathrm{b})$. 
floating charges legislation does not give specific details on the matter. Could it be possible then that a floating charge instrument "is not a deed and has immediate effect on execution"? ${ }^{69}$ This would be consistent with the previous position but that was dependent upon the clear statutory wording to that effect, which has now been repealed. To fit in with wider Scots law, delivery would probably be necessary (except perhaps where the charge instrument is a bilateral document). ${ }^{70}$ It would also be the more sensible approach since the chargee is the party who has most interest in the registration of the charge, and they will only be in a position to register after the instrument has been delivered to them.

As execution will always precede delivery of the instrument, the safest option for a chargee is, nevertheless, to use the execution date as the starting point for the timed period for registration. The execution date will also be more easily discernible than the delivery date, by simply viewing the instrument, unless the delivery date is also added to the instrument. ${ }^{71}$ In any event, the Registrar of Companies generally accepts the creation date specified by the party submitting documents for registration. Once the Registrar decides to register, the chargee will be issued with a certificate, which is "conclusive evidence" that the required documentation was delivered to the Registrar within the relevant period. ${ }^{72}$

If a floating charge's creation date is now the date when the instrument is delivered to the chargee, there may be an issue with the floating charge ranking provisions involving negative pledges. ${ }^{73}$ Those provisions refer to the "instrument creating a floating charge...", 74 and provide that if such an instrument contains a negative pledge this will "confer priority on the floating charge over any fixed security or floating charge created after the date of the instrument". ${ }^{75}$ It seems more likely that the "date of the instrument" is its execution date rather than its delivery date, due to the former ordinarily being considered to represent an instrument's

\footnotetext{
${ }^{69} \mathrm{~S} 859 \mathrm{E}(1)$.

${ }^{70}$ For the general position in Scots law, see e.g. H L MacQueen, "Delivery of Deeds and Voluntary Obligations" in A J M Steven, R G Anderson and J MacLeod (eds), Nothing so Practical as a Good Theory: Festschrift for George L Gretton (2017) 102 at 104, and the authorities cited there. It may be contended that delivery is only necessary to complete a unilateral written juridical act and is not required where both parties have executed.

${ }^{71}$ Patrick (n 1) at 22 suggests adding a delivery date to execution blocks on unilateral Scottish charge documents, such as floating charges, to evidence the date of creation for Companies House.

${ }^{72} \mathrm{~S} 859 \mathrm{I}(6)$.

${ }^{73}$ It may be that this was simply overlooked when the registration of charges system was reformed.

${ }^{74}$ Companies Act 1985 s 464(1) and (1A).

${ }^{75}$ Companies Act 1985 s 464(1A). Emphasis added.
} 
date. Also, the provision regarding the ranking priority conferred by a negative pledge (in $\mathrm{s}$ 464(1A) of the Companies Act 1985) was brought into effect after the decision in AIB Finance $v$ Bank of Scotland ${ }^{76}$ in which it was held that a floating charge with a negative pledge had priority from its execution date against subsequently created voluntary securities. ${ }^{77}$ Rather than legislatively overruling AIB Finance, the provision appears to reinforce the decision.

In the event that the priority date of a floating charge with negative pledge does not align with its creation date for registration of charges purposes, it could lead to odd results. For example, if a floating charge instrument containing a negative pledge was executed by a company on day one, and not delivered until day ten, and the charge was sent for registration on day thirty, then the time period for registration would have been complied with (within twenty-one days beginning with the day after the date of delivery) but the floating charge would rank from a date prior to that period. This would be an unacceptable elongation of the "invisibility period". Even more problematic would be if a floating charge was considered to have priority from its execution date without the instrument ever being delivered, meaning that the time period for registration would never commence. This outcome would be absurd and must be dismissed.

It may be that the terms "instrument creating a floating charge" and "date of the instrument" could be given an interpretation that refers to the date of delivery of the instrument to the chargee. Perhaps the reference to "date of the instrument" can be considered subject to the condition that the charge must be effective, which requires delivery, and priority can only be conferred from this point. However, if such an interpretation is considered too strained, a minor statutory rectification would be necessary, if the delivery date is to be the priority point. In the meantime, the fact that the delivery date equating to the creation date does not readily fit with the wording of the ranking provision could bolster the argument that the creation date is instead the date of the charge instrument's execution.

Despite this discussion about whether a floating charge is created for registration purposes on its execution or delivery date, it should be stated that the most appropriate date for a floating charge taking effect would be upon its registration. Until registration in the charges register there is no publicity regarding the creation of a floating charge. However, the law is

\footnotetext{
761993 SC 588. The Companies Act 1985 s 464(1A), was actually added by the Companies Act 1989 s 140(4), but was only brought into force on 3 July 1995.

${ }^{77}$ A standard security granted on the same day as the floating charge in AIB Finance ranked behind the floating charge as the standard security was only later recorded in the Sasine Register, and this "creation" was prohibited by the floating charge's negative pledge.
} 
unlikely to be reformed in this direction any time soon, given that Part 2 of the Bankruptcy and Diligence etc (Scotland) Act 2007, which would have resolved the issue, ${ }^{78}$ has unfortunately not been brought into force. ${ }^{79}$

\section{E. EFFECTIVENESS OF UNREGISTERED CHARGES}

\section{(1) General}

The old registration of charges system was criticised for its uncertainty regarding the precise consequences for a charge where the registration requirements were not met. ${ }^{80}$ The wording of the relevant provision under the new regime, in s $859 \mathrm{H}$, is in almost exactly the same terms as previously and, therefore, the problem has not been dealt with. Where there has been a failure to deliver a registrable charge within the required period, s $859 \mathrm{H}(3)$ provides that:

“the charge is void (so far as any security on the company's property or undertaking is conferred by it) against-

(a) a liquidator of the company,

(b) an administrator of the company, and

(c) a creditor of the company".

Section $859 \mathrm{H}(4)$ states that the voidness under (3) is "without prejudice to any contract or obligation for repayment of the money covered by the charge; and when a charge becomes void under this section, the money secured by it immediately becomes payable". Thus, noncompliance with the registration requirements automatically accelerates the obligation to repay any loan or other "secured" sum. ${ }^{81}$

The focus here will be on the status of a charge itself where the registration requirements have not been fulfilled. By specifying that a charge is void only against certain parties, the implication is that it remains valid in other respects. Since the relevant provision

\footnotetext{
${ }^{78}$ By introducing a Register of Floating Charges and providing that a floating charge would not have effect until its registration in that register.

${ }^{79}$ Yet it should be noted there is some support in England for registration being used as the point at which a security right is created (in line with the general Scots law approach): see e.g. R Calnan, "What Makes a Good Law of Security?" in F Dahan (ed), Research Handbook on Secured Financing in Commercial Transactions (2015) 451 at 463-464.

${ }^{80}$ See Gretton (n 2) at 164-168. There were previously criminal consequences for failure to comply with the registration requirements too; however, these have been abolished.

${ }^{81}$ See Gretton (n 2) at 164-5, for criticism of the statutory acceleration provision.
} 
applies across the UK, and in the absence of Scottish authority, it is worthwhile to consider the relevant law in England. English law may help to explain the contexts in which a non-registered charge remains effective and will be referred to in the following sub-sections.

\section{(2) Against the Company}

There is no mention of the charge being void against the chargor company. In English law, the chargor is one party against whom the charge does continue to have effect. ${ }^{82}$ Such effectiveness could enable the chargee (e.g. a standard security holder in Scots law) to enforce its security and realise the encumbered property and obtain proceeds. ${ }^{83}$ The security would be invalid against a liquidator, administrator or another secured creditor of the company and therefore any of these parties could seek to deal with the property without giving effect to the chargee's security. However, it may be that if the chargee successfully realises the property before the company enters liquidation or administration, and there is not (yet) a competing secured creditor, then the voidness of the chargee's security against those parties becomes immaterial. Indeed, the property will no longer be owned by the chargor and the security will have been extinguished anyway. The same is essentially true in English law, where the charge is considered "exhausted" or "spent" after its enforcement and thus its status as a void security against certain parties is irrelevant. ${ }^{84}$

If a charge is effective against the company without being registered and is only effective against third parties if registration takes place, the position is reminiscent of the "attachment" and "perfection" distinction within a UCC Art 9/PPSA system. Creation of the charge corresponds to its attachment (i.e. its effectiveness against the company) and registration in the charges register can be considered the perfection stage. Some commentators on English law in fact refer to the registration of charges regime in these terms. ${ }^{85}$ However, the

\footnotetext{
${ }^{82}$ So long as the company is not in liquidation or administration. See Re Monolithic Building Co [1915] 1 Ch 643 per Lord Cozens-Hardy MR at 667 and Phillimore LJ at 667; Independent Automatic Sales Ltd v Knowles \& Foster [1962] 1 WLR 974; Smith v Bridgend County Borough Council [2002] 1 AC 336 per Lord Hoffmann at para 21 and per Lord Scott of Foscote at paras 65-67. See also McKendrick (ed), Commercial Law (n 40) para 24.50.

${ }^{83}$ If the security was not effective even in this context, then the creditor would need to use diligence to obtain a right in relation to the property.

${ }^{84}$ McKendrick (ed), Commercial Law (n 40) para 24.51; P L Davies and S Worthington, Gower's Principles of Modern Company Law 10 ${ }^{\text {th }}$ edn (2016) para 32-29, fn 180. See also the Australian case Re Row Dal Constructions Pty Ltd [1966] VR 249.

${ }^{85}$ E.g. L Gullifer (ed), Goode and Gullifer on Legal Problems of Credit and Security, $6^{\text {th }}$ edn (2017) para 2-23; McKendrick (ed), Commercial Law (n 40) chs 23-24.
} 
comparison can only be taken so far as, for example, a charge can have effect against third parties within the delivery period before registration takes place. Further, the attachment and perfection distinction does not correspond well to a floating charge, at least in Scots law. The floating charge still requires crystallisation (confusingly also known as "attachment") in order to affect third parties, in addition to registration in the charges register. A further point which seems to undermine registration as a single perfection point is that for assignation in security the security would only be effective once intimation occurs.

\section{(3) Against an Acquirer of Property}

Another party against whom an unregistered charge may remain effective is a party acquiring property from the chargor. Again, this is the position in English law but it may be questioned whether this is altogether satisfactory. ${ }^{86}$ The existence of a standard security in Scots law would be identifiable from the Land Register but the absence of registration in the charges register could cause an intending transferee to consider a standard security to be invalid. A potentially relevant point is that a purchaser is a creditor of the seller company, ${ }^{87}$ and this status may even persist after ownership is transferred, if there are continuing obligations. Therefore, if an unregistered charge is ineffective against unsecured creditors, a purchaser could be protected.

\section{(4) Against Unsecured Creditors}

Despite the reference to "a creditor of the company" in s $859 \mathrm{H}(3)$, it may be the case that an unregistered charge is in fact valid against unsecured creditors. In English law, the reference has been held not to extend to unsecured creditors, except where the company has entered liquidation or administration. ${ }^{88}$ This is because these parties do not have property rights and

\footnotetext{
${ }^{86}$ In McKendrick (ed), Commercial Law (n 40) para 24.52 it is stated that a purchaser is bound by an unregistered charge "for some curious reason". The Companies Act 1989 s 95, inserting s 399 into the Companies Act 1985, would have made an unregistered charge void against a purchaser but this never came into force. More recently, the Department of Business, Innovation and Skills (as it then was) also expressed an interest in making such an amendment (Government Response - Consultation on Registration of Charges created by Companies and Limited Liability Partnerships (December 2010), proposal F); however, this did not lead to any change in the 2013 reforms and has been described as an "opportunit[y] missed" - Gullifer (ed), Legal Problems of Credit and Security (n 85) para 2-23.

${ }^{87}$ See R G Anderson, "Fraud on Transfer and on Insolvency: Ta...Ta... Tantum et Tale?" (2007) 11 EdinLR 187 at 201-202.

${ }^{88}$ See e.g. Gullifer (ed), Legal Problems of Credit and Security (n 85) para 2-23; McKendrick (ed), Commercial Law (n 40) para 24.51; D French, Mayson, French \& Ryan on Company Law, 34 ${ }^{\text {th }}$ edn (2017) para 11.7.3.
} 
therefore cannot interfere with any dealings concerning the property in question. This may also be the position in Scots law. If so, unsecured creditors would need to obtain diligence (or another security) or force the company into liquidation or administration in order for the security to be void against them. Where such a creditor does not take one of these steps, the chargeholder could enforce the security and deplete the assets that might otherwise be available to the unsecured creditors, were the company later to enter an insolvency process.

\section{(5) For Appointment of a Receiver or Administrator}

Insofar as an unregistered floating charge is concerned, if the security remains effective against the company, does this allow for the appointment of a receiver (where still possible) or an administrator? There is no mention of an unregistered charge being void against a receiver. ${ }^{89}$ There would, however, be difficulties in the operation of a receivership if other parties, such as secured creditors, could simply ignore the receiver's existence due to the relevant floating charge's voidness against them. The process would have the status of a ghost receivership. In relation to administration, an unregistered charge is expressly void against an administrator and therefore such a charge surely could not allow for its holder to appoint an administrator out of court $^{90}$ where the charge would not be recognised as a security by that administrator. This argument may be supported by the fact that an administrator cannot be appointed if the floating charge is "not enforceable", and if the meaning of this extends to where the charge has not been validly registered..$^{91}$

\section{(6) Against Claim Debtors}

For the assignation in security of a claim, an unregistered assignation in security may remain valid against the claim debtor. Claim debtors are not creditors of the cedent (they are the cedent's debtors) so the void effect does not seem to apply to them. If this is the law, it entitles

\footnotetext{
${ }^{89}$ If, instead, it was another chargeholder who had appointed the receiver, the unregistered charge would presumably not have practical effect due to it being void against that other chargeholder.

${ }^{90}$ Under Insolvency Act 1986 Sch B1, para 14. It would, of course, be possible for the creditor to apply to the court for the appointment of an administrator, as holding a charge is not necessary for such an application: Insolvency Act 1986 Sch B1, para 12(1)(c). ${ }^{91}$ Insolvency Act 1986 Sch B1, para 16. And see Re Euromaster Ltd [2012] EWHC 2356 $(\mathrm{Ch})$ per Norris $\mathrm{J}$ at para 11 . There is some doubt on this point, however, for although the charge is not fully enforceable, it may still be enforced against the company (and potentially against certain other parties too). There is also uncertainty as to what the position would be if an attempt was made to appoint an administrator before the expiry of the registration period and there was ultimately a failure to register.
} 
the chargee to payment from the claim debtor, unless a liquidator, administrator or (secured) creditor of the company intervenes. ${ }^{92}$

\section{(7) Against Other Parties}

There are certain other parties against whom an unregistered charge may also continue to be effective. A company is able to grant a security (except a floating charge) in its capacity as a trustee $^{93}$ and such a security can be a registrable charge. ${ }^{94}$ Trust property is excluded from the liquidation and administration of the company but the company's trust estate can be separately subject to a sequestration. ${ }^{95}$ Does the absence of reference to a trustee in sequestration in $\mathrm{s}$ $859 \mathrm{H}$ mean that a charge could be effective against such a party? And are trust creditors, whether secured or not, included within the meaning of "a creditor of the company"? Given that charges over trust property are registrable under the regime, it is presumed that an unregistered charge over trust property is at least void against those who hold security over the property held in trust. If the charge is still valid against even these creditors, the whole purpose of applying the regime to trust property would be unacceptably defeated.

Considering the effectiveness issue as a whole, it would be much simpler if an unregistered charge was rendered entirely void. ${ }^{96}$ The above difficulties ascertaining the particular ongoing relevance of the charge would be removed and it would act as a further incentive for registration in accordance with the regime. However, with reference to the law as it currently stands, the foregoing analysis (with the assistance of English law) identifies contexts in which an unregistered charge could still be effective.

\footnotetext{
${ }^{92}$ For scepticism about this, see Gretton (n 2) at 168.

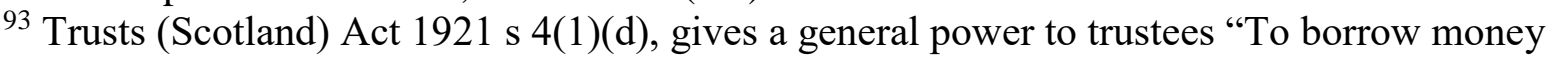
on the security of the trust estate or any part thereof, heritable as well as moveable".

${ }^{94}$ For discussion, see MacPherson (n 38) at 6ff. A statement can even be given to the Registrar of Companies detailing that it is holding charged property as a trustee: Companies Act 2006 s 859J.

${ }^{95}$ Bankruptcy (Scotland) Act 2016 s 6(1)(a); Turnbull v Liquidator of Scottish County Investment Co 1939 SC 5; Smith v Liquidator of James Birrell Ltd (No 2) 1968 SLT 174; and Gibson v Hunter Home Designs Limited 1976 SC 23.

${ }^{96}$ The provisions regarding ongoing effectiveness fit better with the relative effects of security rights in English law than they do with the personal and real rights distinction in Scots law.
} 


\section{F. REGISTRATION OF CHARGES OVER ACQUIRED PROPERTY}

Ordinarily, the registration of charges is relevant where a company is granting a security over its property. There is also, however, a registration provision (s 859C) that applies "where a company acquires property or undertaking which is subject to a charge of a kind which would, if it had been created by the company after the acquisition of the property or undertaking, have been capable of being registered under s 859A". ${ }^{97}$ The Registrar must register the charge if "the company or any person interested in the charge" delivers a s 859D statement of particulars, as well as a certified copy of the charge instrument. Yet, in various respects, there is uncertainty as to the relevance and practical application of s 859C for security rights in Scots law.

\section{(1) Standard Security}

Section 859C could operate where, for example, A Ltd has created a standard security in favour of $\mathrm{B}$, the security has been registered in the charges register, and then A Ltd transfers ownership of the encumbered land to C Ltd. The provision would enable C Ltd or, more likely, B, to have the standard security registered as a charge against C Ltd in the charges register. But this form of registration is not compulsory, in terms of the charge's effectiveness or otherwise. The criminal offence for failing to deliver the required documentation has been abolished. ${ }^{98}$

Even if there is no registration in the charges register for C Ltd, it will be clear from the Land Register that the property remains subject to B's security after the transfer, assuming that the security has not been discharged. From the perspective of a party interested in dealing with C Ltd, it would be useful to have details of the security in the charges register for C Ltd, along with other details of security rights affecting that party's property. However, there is currently little incentive for C Ltd or B to actually seek registration in the charges register, given that the security has ongoing validity without that registration.

\section{(2) Assignation in Security}

With an assignation in security in Scots law, there is a transfer of the property to the chargee. ${ }^{99}$ It would therefore be nonsensical if the assignation could be registered under s 859C as a charge against the company that is the secured creditor. ${ }^{100}$ For example, if a claim is assigned in

\footnotetext{
${ }^{97} \mathrm{~S} 859 \mathrm{C}(1)$.

98 The relevant provisions were the Companies Act 2006 s 880(3)-(4).

${ }^{99}$ See $\mathrm{n} 25$.

100 The position would be different if an assignation in security only created a subordinate right in the property.
} 
security by A Ltd to B Ltd, this means that the property is transferred to B Ltd and therefore allowing the registration of the charge in the charges register for B Ltd would show it holding the security over its own property. In addition, the provision is of no application for further transfers of property assigned in security. If property is retrocessed to the chargor, then the security is extinguished. The same inapplicability issue is true of transfers to other parties. For instance, C Ltd is the assignee (and thus the chargee) and further assigns to D Ltd and when that transfer is completed, it is C Ltd, rather than the chargor, who has transferred the property. By doing so, C Ltd has also lost the security over the property that could have enabled registration (as this form of security is dependent upon C Ltd holding the property).

\section{(3) Floating Charge}

Section 859C registration also has no obvious relevance to floating charges in Scots law. By its nature, a floating charge will not affect property that is transferred by the chargor. ${ }^{101}$ As such, it will not be possible for the chargeholder (or anyone else) to have the charge registered against a transferee company. If a floating charge has attached, the chargor company will be in the midst of receivership, liquidation or administration and the realisation of property by these parties will release the property from the ambit of the floating charge.

\section{G. CONCLUSION}

The merits of the registration of charges regime often go unmentioned. It provides a freely accessible register which discloses a range of useful information to interested parties with respect to security rights created by a company. Our system of security rights is fragmented, with various forms of security that are constituted in different ways. There is consequently value in having a register which acts as a single source of information regarding "charges" that a company has created. But it is certainly true that the regime suffers from significant flaws, such as its unreliability with respect to the existence of security rights, either because of the period after a charge becomes effective in which its existence may not be ascertainable from the register or because a number of security devices are not registrable charges. While the

\footnotetext{
101 The floating charge encompasses property that is "from time to time" in the company's "property and undertaking": Companies Act 1985 s 462. And see MacMillan v T Leith Developments Ltd [2017] CSIH 23; 2017 SC 642, per Lord Drummond Young at para 77.
} 
introduction of a UK-wide registration of charges system was a sensible development, a number of existing weaknesses have not been directly addressed. ${ }^{102}$

It is possible, however, that the current statutory definition of "charge" could correspond to a wider understanding of security rights in Scots law, which would allow for the charges register to provide more extensive information regarding security rights created by a company. This position would also involve further uniformity between Scots law and English law as regards the notion of registrable charges but in a manner that is not inconsistent with a wide interpretation of security rights in the underlying Scots law.

With reference to creation dates of charges, the new regime has retained the creation date of a standard security, but it is unfortunate that information-sharing powers have not been utilised to avoid the necessity of dual registration. For assignation in security, making the general creation date the date when the assignation is delivered to the assignee will, in some cases, minimise the period between the security becoming effective (through intimation) and it being disclosed on the register. Yet it does not resolve the latter issue and it also means that an assignation is "created" before it has effect against parties in wider law. With reference to floating charges, the creation date is not wholly certain and there may be a discrepancy between that date for the registration of charges regime and for ranking where there is a negative pledge. Furthermore, there remains an undesirable invisibility period between the private act creating the charge and the disclosure of the charge on the charges register.

This article also considered the effect of a charge where there has not been compliance with the registration regime. In the absence of Scottish authority, this is an area in which English law could prove influential regarding interpretation, especially in light of the provisions applying across the UK jurisdictions. It may be that an unregistered charge remains valid against parties such as the company itself, unsecured creditors, acquirers of property from the company and claim debtors (for assignation in security). The final section demonstrated that the provisions for the registration of charged property later acquired by a company have little practical value for standard securities and appear to be irrelevant for assignation in security and floating charges. Thus, they serve no substantive purpose in Scots law.

Overall, the new regime can be considered an improvement on the old law. The discussion of various issues above shows, however, that there is still much to be determined

\footnotetext{
${ }^{102}$ For some criticisms and further suggested reforms from an English law perspective, see e.g. L Gullifer and M Raczynska, "The English Law of Personal Property Security: Underreformed?" in L Gullifer and O Akseli (eds), Secured Transactions Law Reform: Principles, Policies and Practice (2016) 271 at $284 \mathrm{ff}$.
} 
regarding the law of registration of charges and it ought to be considered an area of significant academic and practical interest, within Scotland and beyond. 